\title{
Adrenal Myelolipoma: A Case Presentation
}

\author{
Adrenal Myelolipom: Olgu Sunumu
}

\author{
Enis Kervancıoğlu, Eray Hasırcı, Ayhan Dirim, Yüksel Cem Aygün \\ Başkent University Faculty of Medicine, Department of Urology, Ankara, Turkiye
}

\begin{abstract}
Adrenal myelolipomas are non-functional benign tumors of hematopoietic and mature adipose tissue. Adrenal myelolipomas, which are generally detected in post-mortem examinations, have become more detectable thanks to evolution and frequent use of imaging techniques. This presentation elaborates on a case of 35-year old male patient presenting with no complaint but diagnosed with adrenal myelolipoma in histopathological examination following surrenalectomy operation for an adrenal mass incidentally detected on ultrasonography and computed tomography work-up.
\end{abstract}

Keywords: Adrenal, Myelolipoma, Benign tumor

Öz

Adrenal myelolipomlar hematopoetik ve matür yağ dokusundan oluşmuş non-fonksiyone benign tümörlerdir. Genelde otopsilerde tespit edilen adrenal myelolipomların, görüntüleme tekniklerinin gelişmesi ve sık kullanımı nedeni ile tespit edilebilirliği artmıştır. Bu sunumda 35 yaşında aktif yakınması olmayan erkek hastada ultrasonografi ve bilgisayarlı tomografi ile insidental olarak adrenal kitle tespit edilip sürrenalektomi operasyonu uygulanan ve histopatolojik inceleme sonucu adrenal myelolipom tanısı konulan olgu bildirilmektedir.

Anahtar Kelimeler: Adrenal, Miyelolipom, Benign tümör

\section{Introduction}

Adrenal myelolipoma is a rare type of benign tumors accounting for 2-4\% of all adrenal tumors (1). Its histological structure contains mature adipose tissue and hematopoietic elements of myeloid and erythroid cells. Although it has quite a typical radiological presentation, misdiagnosis is frequent due to its rare manifestation. Since most of the cases are detected as asymptomatic incidental imaging findings, adrenal myelolipomas are also named as "insidentoma". This condition was first defined in 1905 by Gierkel and was later named in 1929 by Oberling (2). It is a mostly unilateral, asymptomatic and hormonally inactive condition, and mostly seen in the age group of 40-60 years with a similar gender distribution. Most adrenal myelolipomas are smaller than $5 \mathrm{~mm}$ in diameter. Surgically removed cases are rare in the literature but detection rates are rising today with frequent use of imaging modalities including ultrasonography (USG), computed tomography (CT) and magnetic resonance imaging (3).

\section{Case Presentation}

A hyperechoic-slightly heterogeneous solid mass measuring $113 \times 83 \mathrm{~mm}$ and showing minimal lobular contour was detected on the right adrenal gland in a 35-year-old male patient during USG done for right lumbar pain. Urine analysis, full blood count, prothrombin time and serum electrolytes were normal. CT taken for further investigation revealed a $103 \times 110 \mathrm{~mm}$ heterogeneous lesion with smooth contours and limited fat density on the lateral side of the right suprarenal tissue (Figure 1). Hormonal analysis indicated inactivity. Open adrenalectomy was performed with a preliminary diagnosis of a mass in the supra renal gland. Macroscopic work-up of the surgical specimen revealed a $12 \times 12 \mathrm{~cm}$ red-orange colored mass (Figure 2). Histopathological examination showed myelolipoma containing mature adipose tissues and hematopoietic elements. The patient was discharged on the $4^{\text {th }}$ postoperative day.

Correspondence: Enis Kervancıoğlu MD, Başkent University Faculty of Medicine, Department of Urology, Ankara, Turkiye

Phone: +90 3122120630 E-mail: enis14@yahoo.com ORCID-ID: orcid.org/0000-0003-3465-9092

Received: 25.01.2017 Accepted: 07.03.2017

Cite this article as: Kervancıoğlu E, Hasırcı E, Dirim A, Aygün YC. Adrenal Myelolipoma: A Case Presentation. J Urol Surg 2018;5(1):39-40.

๑Copyright 2018 by the Association of Urological Surgery / Journal of Urological Surgery published by Galenos Publishing House. 


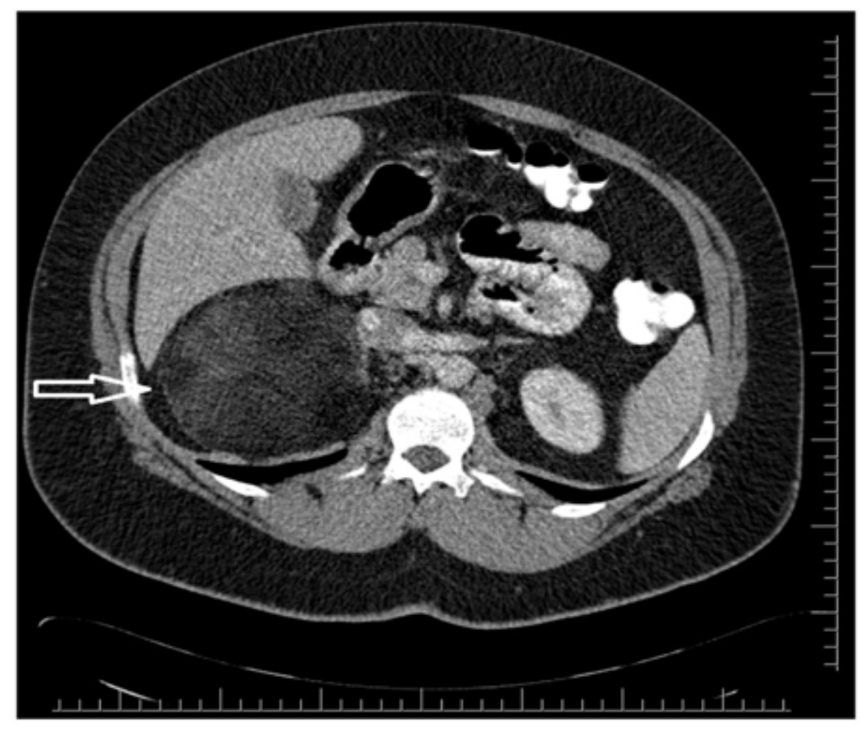

Figure 1. Conformal contour with heterogeneous mass in limited fat densities in the right adrenal gland in computed tomography

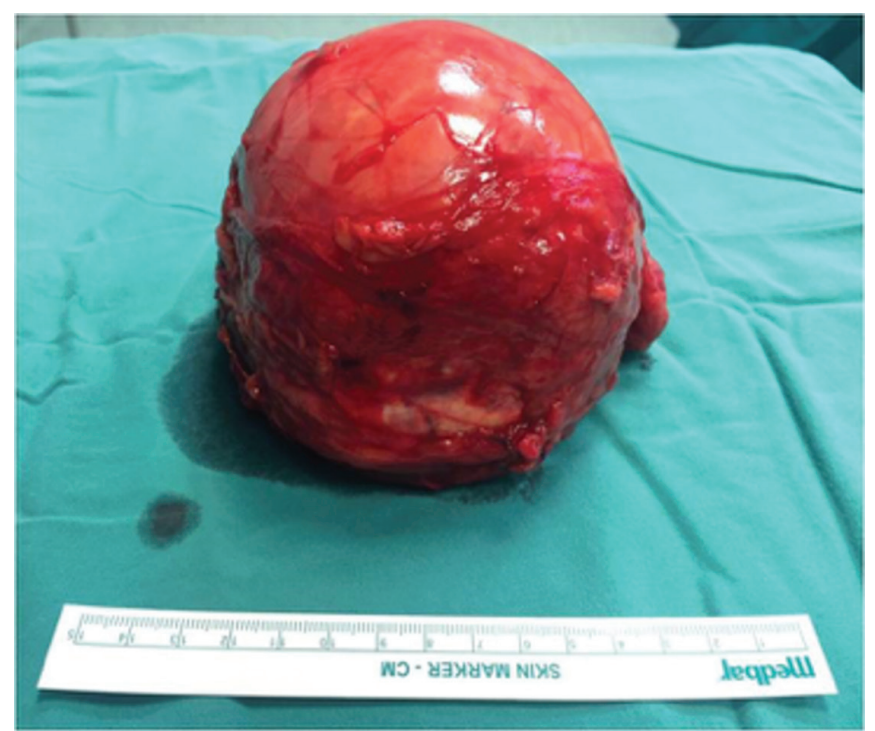

Figure 2. Macroscopic appearance of adrenal gland

\section{Discussion}

Adrenal myelolipomas are non-functional benign tumors of hematopoietic and mature adipose cells. Although they are generally unilateral in presentation and hormonally inactive, about 10\% may be associated with endocrine diseases including Cushing's syndrome, congenital adrenal hyperplasia, Conn's syndrome, pheochromocytoma, and hyperthyroidism (4). There are many theories about their formation but the most accepted one is that they are formed as a result of metaplastic changes taking place in reticuloendothelial cells of blood vessels upon stimulations such as necrosis, infection and stress (5). The incidence of myelolipoma detected at autopsy is between $0.08 \%$ and $0.4 \%$ most myelolipomas reported in the literature are small tumors $(0.5-5 \mathrm{~cm})(3)$. About $10 \%$ of adrenal myelolipomas may grow and become symptomatic. The main complication of large myelolipomas is acute hemorrhage causing side or back pain. There was no other adrenal disease in this patient. The mass was $12 \mathrm{~cm}$ in diameter and it caused right lumbar pain. The generally accepted rule is to treat asymptomatic, hormonally inactive myelomas smaller than $6 \mathrm{~cm}$ conservatively, whereas to surgically remove symptomatic or complicating myelomas larger than $6 \mathrm{~cm}$ in diameter (6). Surgical treatment was preferred for this patient since the mass was very large and caused pain.

\section{Ethics}

Informed Consent: Consent form was filled out by the patient.

Peer-review: Externally peer-reviewed.

\section{Authorship Contributions}

Surgical and Medical Practices: E.K., Y.C.A., Concept: E.K., Design: A.D., Data Collection or Processing: E.H., Analysis or Interpretation: E.K., Literature Search: E.K., E.H., Writing: E.K.

Conflict of Interest: No conflict of interest was declared by the authors.

Financial Disclosure: The authors declared that this study received no financial support.

\section{References}

1. Anis-UI-Islam M, Qureshi AH, Zaidi SZ. Adrenal myelolipoma in a young male - a rare case scenario. J Pak Med Assoc 2016;66:342-344.

2. Hakim A, Rozeik C. Adrenal and extra-adrenal myelolipomas - a comparative case report. J Radiol Case Rep 2014;8:1-12.

3. Gershuni VM, Bittner JG 4th, Moley JF, Brunt LM. Adrenal myelolipoma: operative indications and outcomes. J Laparoendosc Adv Surg Tech A 2014;24:8-12.

4. Inuzuka $M$, Tamura $N$, Sone $M$, Taura $D$, Sonoyama $T$, Honda $K$, Kojima K, Fukuda Y, Ueda Y, Yamashita Y, Kondo E, Yamada G, Fujii T, Miura M, Kanamoto N, Yasoda A, Arai H, Mikami Y, Sasano H, Nakao K. A case of myelolipoma with bilateral adrenal hyperaldosteronism cured after unilateral adrenelectomy. Intern Med 2012;51:479-485.

5. Tyritzis SI, Adamakis I, Migdalis V, Vlachodimitropoulos D, Constantinides CA. Giant adrenal myelolipoma, a rare urological issue with increasing incidence: a case report. Cases J 2009;2:8863.

6. Nabi J, Rafiq D, Authoy FN, Sofi GN. Incidental detection of adrenal myelolipoma: a case report and review of literature. Case Rep Urol $2013 ; 2013: 789481$. 